\title{
Apropriasi Budaya Suku Banjar dalam Gaya Kepemimpinan Gubernur Kalimantan Selatan Sahbirin Noor
}

\section{Appropriation of Banjar Ethnic Culture in Leadership Style of South Borneo Governor Named Sahbirin Noor}

\author{
Toto Fachrudin \\ Pemimpin Redaksi Radar Banjarmasin \\ Alamat: Jalan A. Yani, Landasan Ulin Tim., Kec. Landasan Ulin, Kota Banjar Baru, \\ Kalimantan Selatan, Indonesia 70721 \\ Email: edukasiterdepan@gmail.com
}

\begin{abstract}
Abstrak
Fenomena penggunaan simbol etnik sebagai identitas budaya menjadi cara yang efektif untuk memengaruhi publik dalam mencapai tujuan politik, menarik untuk dikaji lebih mendalam. Penelitian ini bertujuan untuk menggambarkan bagaimana cara Sahbirin Noor menampilkan dirinya dengan menggunakan identitas diri sebagai Paman Birin. Teori apropriasi budaya digunakan untuk melihat bagaimana identitas budaya diadaptasi dalam kepemimpinan kepala daerah. Penggunaan simbol etnik dan identitas budaya, termasuk di dalamnya bagaimana cara berbicara, bersikap, dan bertindak, dalam gaya kepemimpinan kepala daerah menjadi kajian penelitian ini. Metode penelitian ini kualitatif, dengan menggunakan metode studi kasus terhadap kepemimpinan Gubernur Kalimantan Selatan Sahbirin Noor. Data dalam penelitian ini didapatkan dengan melakukan observasi keseharian Gubernur Kalimantan Selatan Sahbirin Noor. Wawancara mendalam kepada warga masyarakat, aparat, budayawan, tokoh masyarakat. Hasil penelitian ini menunjukkan bahwa panggilan Paman Birin yang melekat pada dirinya menjadi identitas budaya, karena mencitrakan dirinya sebagai bagian dari kekerabatan kultural dengan seluruh warga Kalimantan Selatan yang bersuku Banjar. Paman Birin menjadi identitas simbolik diri dan identitas budaya yang diadaptasi dari nilai-nilai budaya Suku Banjar dalam kepemimpinan Gubernur Kalsel Sahbirin Noor. Apropriasi budaya Banjar ini terlihat dari cara berkomunikasi, gaya bicara, sikap, maupun penggunaan atribut pakaian Gubernur Kalsel Sahbirin Noor.
\end{abstract}

Kata Kunci: apropriasi budaya, Paman Birin, identitas budaya, pemilihan gubernur, gaya kepemimpinan, budaya Suku Banjar

\begin{abstract}
The phenomenon of using ethnic symbols as cultural identities to become an effective way to influence the public in achieving political goals is interesting to be studied in more depth. This study aims to describe how Sahbirin Noor presents himself by using his identity as Uncle Birin. Cultural appropriation theory is used to see how cultural identity is adapted in the leadership of regional heads. The use of symbols of ethnicity and cultural identity, including how to speak, behave, and act, in the leadership style of regional heads is the study of this research. This research method is qualitative, using a case study method on the leadership of the Governor of South Kalimantan named Sahbirin Noor. The data in this study were obtained by observing the daily life of the Governor of South Kalimantan, Sahbirin Noor. In-depth interviews were done to the community members, officials, culturalists, community leaders. The results of this study indicate that the nickname of Uncle Birin that is attached to him becomes a cultural identity, because he imaged himself as part of cultural kinship with all South Kalimantan residents who are Banjarese. Uncle Birin became a self-symbolic identity and cultural identity adapted from the cultural values of the Banjar Ethnic in the leadership of the Governor of South Kalimantan named Sahbirin Noor. This appropriation of Banjar culture can be seen from the way of communicating, speaking style, attitude, and the use of clothing attributes of the Governor of South Kalimantan named Sahbirin Noor.
\end{abstract}

Keywords: cultural appropriation, Uncle Birin, cultural identity, governor election, leadership style, Banjar ethnic culture 
Biokultur, 2021, 10 (2): 120-134. DOI: http://dx.doi.org/10.20473/bk.v10i2.31685

Article History:

Received November 25, 2021; Accepted November 30, 2021; Published Online December 22, 2021.

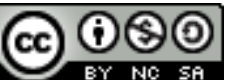

\section{Pendahuluan}

Karakteristik budaya Suku Banjar digunakan dalam proses pemilihan kepala daerah di Indonesia, termasuk pemilihan gubernur. Budaya yang sering menjadi rujukan dalam menentukan cara bersikap, berpikir, bertingkah laku, hingga cara bicara dan berinteraksi adalah tata nilai yang dapat mengikat karena adanya kesamaan. Tata nilai dalam budaya sering diadopsi dalam gaya kepemimpinan secara simbolik untuk menunjukkan adanya kesamaan identitas dengan warga masyarakat dari suku besar yang berdomisili di wilayah tertentu, sebagai cara untuk membangun relasi sosial berdasarkan nilai-nilai budaya.

Apropriasi nilai-nilai budaya dalam gaya kepemimpinan kepala daerah ini terlihat dipraktikkan oleh Gubernur Kalimantan Selatan Sahbirin Noor dalam kesehariannya. Dengan menyebut dirinya sebagai Paman Birin, Gubernur Kalsel Sahhbirin Noor ingin menunjukkan identitas dirinya sebagai bagian dari kekerabatan budaya Banjar, sehingga gaya kepemimpinannya lebih mudah diterima karena adanya kesamaan dalam rujukan tata nilai budaya.

Dalam kesehariannya, baik interaksinya secara langsung dengan masyarakat, atau saat menjalankan fungsi kepala pemerintahan, Sahbirin Noor terlihat tampil dengan simbol-simbol budaya. Ia mengadopsi semua nilai budaya Banjar dalam kesehariannya, sehingga ia lebih dikenal dan populer sebagai Paman Birin, ketimbang dikenal sebagai Gubernur Kalimantan Selatan.

Apa yang dilakukan Sahbirin Noor bila mengacu pada teori adaptation and cultural appropriation yang dikembangkan Julie Sanders (2006: 26), adalah bentuk adaptasi dan transformasi tradisi budaya masyarakat Banjar yang religius dalam gaya kepemimpinannya. Sanders menjelaskan bahwa di sisi lain apropriasi sangat memengaruhi perjalanan yang lebih menentukan dari sumber informasi ke dalam produk dan kekuasaan budaya yang sama sekali baru.

Apropriasi juga melihat bagaimana subyek (agen) yang berperan sebagai penerima (objek) dengan cara adaptasi hingga menjadikannya milik sendiri. Dengan kata lain, bagaimana Sahbirin Noor beradaptasi dengan lingkungan birokrasi sebagai kepala daerah dengan menjadi Paman Birin, sehingga menjadikannya lebih mudah untuk berinteraksi dan berkomunikasi dengan masyarakat sebagai sesama urang Banjar.

Dari pemahaman tersebut dapat disimpulkan bahwa apropriasi adalah menjadikan nilai-nilai dan tradisi budaya Banjar sebagai identitas diri Sahbirin Noor, dengan menyesuaikan simbol, bahasa, dan kebiasaan masyarakat Banjar dalam gaya kepemimpinannya sebagai Gubernur Kalimantan Selatan. 
Chris Barker menegaskan, identitas adalah suatu konstruksi sosial budaya. Apa yang dipahami sebagai identitas, menurut Baker adalah soal kesamaan dan perbedaan tentang aspek personal dan sosial, tentang kesamaan individu dengan sejumlah orang dan apa yang membedakan individu dengan orang lain. Dilihat dari bentuknya, setidaknya ada tiga bentuk identitas, yakni identitas budaya, identitas sosial dan identitas pribadi (Barker 2004:173).

Identitas budaya merupakan ciri yang muncul karena seseorang itu merupakan anggota dari sebuah etnik tertentu. Itu meliputi pembelajaran tentang penerimaan tradisi, sifat bawaan, agama, dan keturunan dari suatu kebudayaan. Identitas sosial, terbentuk akibat dari keanggotaan seseorang dalam suatu kelompok kebudayaan. Tipe kelompok itu antara lain, umur, gender, kerja, agama, kelas sosial, dan tempat. Identitas sosial merupakan identitas yang diperoleh melalui proses pencarian dan pendidikan dalam jangka waktu lama.

Identitas pribadi didasarkan pada keunikan karakteristik pribadi seseorang. Seperti karakter, kemampuan, bakat, pilihan dan lain sebagainya. Sementara pengertian konstruksi identitas menurut Chris Barker adalah bangunan identitas diri, memperlihatkan siapa diri mereka sebenarnya dan kesamaannya dengan sejumlah orang dan apa yang membedakan mereka dari orang lain. Pemanfaatan identitas budaya dalam praktik pemerintahan sebagai gaya kepemimpinan adalah bentuk apropriasi. Apropriasi dalam memilih dan menjadikannya sebagai rujukan dalam cara bersikap, berinteraksi, berkomunikasi dan menyesuaikan dengan nilai dan budaya birokrasi yang cenderung formal, kaku dan protokoler.

Apropriasi budaya menjadi salah satu pendekatan yang digunakan kepala daerah sebagai aktor, yang memiliki peran penting dalam menentukan arah kebijakan pembangunan untuk mendorong terciptanya demokrasi lokal yang partisipatif. Zuhro (2009:2-3) menjelaskan setidaknya ada dua alasan penting untuk mengkaji peran aktor dalam proses demokrasi lokal. Pertama, dalam konteks budaya politik lokal, aktor adalah agen budaya. Sebagai agen budaya, aktor merupakan penerus nilai-nilai budaya politik yang tumbuh dan berkembang di ranah lokal. Pada saat yang sama aktor juga pencipta (produsen) budaya, sehingga perilaku politik sang aktor dapat memengaruhi perubahan dan kesinambungan nilai-nilai budaya politik lokal. Kedua, pentingnya peran aktor politik adalah resultan dari proses demokrasi itu sendiri. Proses transisi politik yang terjadi di Indonesia pasca-reformasi 1998 telah menempatkan aktor politik di Indonesia dalam posisi yang jauh lebih strategis daripada masa sebelum reformasi. Ini karena pada masa ini, tercipta suatu dinamika hubungan antara aktor politik di tingkat lokal dan di tingkat nasional.

Selain itu, para aktor lokal juga harus memegang kendali atas dinamika pemerintahan gaya baru yang timbul sebagai konsekuensi logis dari desentralisasi itu sendiri. Pemerintahan gaya baru di tingkat lokal ini memunculkan model pemimpin yang kreatif, inovatif, dan demokratis untuk membawa perubahan dan perbaikan kualitas hidup masyarakat. Pemilihan dan penyesuaian unsur budaya yang diadopsi dalam gaya kepemimpinan kepala daerah bukanlah bentuk budaya baru yang berbeda. Barendregt dan Bogaerts (2016) menyebut pemanfaataan itu sebagai apropriasi, yaitu memilih dan menyesuaikan unsur asing dengan ukuran sendiri agar bisa diterima menjadi hak milik.

Pengertian apropriasi yang lebih luas diungkapkan Rogers (2006), bahwa apropriasi adalah penggunaan simbol budaya, artefak, genre, ritual, dan teknologi oleh anggota budaya yang lain. Ia membagi apropriasi budaya ke dalam empat bentuk, yaitu: pertama; pertukaran secara timbal balik, kedua; dominasi budaya, yaitu penerapan budaya dominan pada budaya bawahan, 
ketiga; eksploitasi budaya, yaitu mengambil budaya bawahan untuk manfaat budaya dominan, dan keempat; transkulturasi, yaitu pencampuran aneka budaya yang tidak bisa disamakan lagi dengan budaya asalnya, atau sebuah pengembangan budaya hibrida. Transkulturasi menempatkan budaya sebagai fenomena relasi yang dibentuk tindakan apropriasi, bukan entitas yang hanya berpartisipasi dalam apropriasi.

Pengertian tersebut memberikan pemahaman bahwa apropriasi bukan praktik "culas" dengan memanipulasi budaya lain untuk mencapai tujuan dan kepentingan pribadi. Karena apropriasi adalah adaptasi dengan saling menyesuaikan atau memodifikasi dua budaya yang sejatinya saling tergantung dan saling menguntungkan. Dalam praktiknya, apropriasi budaya bukan pula sebagai bentuk pencurian atau penyalahgunaan budaya dengan mengambil sebagian atau secara keseluruhan.

Seperti menurut pandangan James O. Young (2008), bahwa apropriasi tidak dapat disamakan dengan manipulasi. Sebab, konsep ini meletakkan penilaian pada konteks pelaku apropriasi, bukan pada konteks budaya sumber. Karena itu, apropriasi dapat dilakukan oleh kedua budaya yang berinteraksi, tanpa mengasumsikan perlunya bentuk baru yang dapat diterima kedua belah pihak. Pemahaman yang diungkapkan James memberi gambaran bahwa budaya birokrasi yang dikenal birokratis, elitis, dan protokoler, tidak selamanya dilihat sebagai budaya yang terikat sistem aturan dan kaku. Sebab, pelaku apropriasi, dalam hal ini adalah pemimpin birokrasi, bisa memberi warna yang berbeda dengan mengadopsi tata nilai budaya lain dalam gaya kepemimpinannya.

Adopsi nilai-nilai dan budaya baru dalam gaya kepemimpinan birokrasi sangat tergantung dari nilai yang dianut pemimpinnya. Bisa jadi budaya biroraksi yang kaku berubah lebih religius dan agamis bila dipimpin oleh seorang kiai atau pemuka agama. Atau lebih dinamis, inovatif dan kreatif bila dipimpin oleh seorang akademisi. Atau bahkan bisa menjadi lebih santai, lebih luwes dan cair bila dipimpin oleh seorang artis atau pesohor. Karena itu, apropriasi budaya dalam gaya kepemimpinan seorang kepala daerah, sangat tergantung dari nilai budaya dan cara pandang yang dianut sebagai rujukan dalam cara berpikir, bersikap, dan berinteraksi. Apropriasi budaya dapat dikatakan sebagai bentuk adopsi atas beberapa elemen budaya lain oleh kelompok budaya yang berbeda. Adopsi ini menggambarkan adanya sebuah proses akulturasi atau asimilasi budaya.

Proses penyesuaian ini dalam bentuk pakaian, musik, seni, agama, bahasa, sikap dan perilaku sosial. Dari pemahaman apropriasi tersebut, maka bahwa apropriasi merupakan adopsi elemen budaya tertentu oleh kelompok budaya berbeda, berupa penggunaan simbol budaya, bahasa, artefak, ritual, kebiasaan, atau teknologi, melalui proses penyesuaian dan adaptasi oleh kedua budaya yang berinteraksi sehingga menjadi hak milik tanpa harus memproduksi bentuk baru yang bisa diterima kedua pihak.

Faktanya bahwa apropriasi budaya Suku Banjar dalam gaya kepemimpinan Gubernur Kalsel Sahbirin Noor membuatnya mendapat kepercayaan masyarakat Kalimantan Selatan untuk menjadi gubernur kedua kalinya. Meski kontestasi pilkada/pilihan kepala daerah yang dilaluinya sangat sengit, bahkan sampai dilakukan Pemungutan Suara Ulang (PSU) berdasarkan keputusan Mahkamah Konstitusi, namun publik masih percaya dan tetap memilihnya dengan kemenangan yang cukup signifikan. 


\section{Metode}

Untuk menggali dan mengungkap bagaimana adaptasi nilai dan tradisi budaya Banjar yang dilakukan Gubernur Sahbirin Noor dalam identitas etnik Paman Birin, peneliti menggunakan pendekatan kualitatif dengan metode studi kasus. Pada dasarnya studi kasus mewakili jenis penelitian kualitatif lainnya (Hancock and Algozzine 2006). Studi kasus berbeda dari tipe lain dalam hal analisis intensif dan deskripsi atau sistem yang dibatasi oleh ruang dan waktu. Topik yang sering diperiksa dalam studi kasus meliputi individu, peristiwa, atau kelompok. Melalui studi kasus, para peneliti berharap untuk mendapatkan pemahaman mendalam tentang situasi dan makna bagi mereka yang terlibat.

Yin (2003) mengungkapkan bahwa penelitian studi kasus mewakili pandangan yang jauh lebih luas, di mana penelitian empiris atas fenomena kontemporer dalam konteks alaminya menggunakan berbagai sumber bukti. Sebagaimana juga Yin (2003) mengungkapan bahwa ada tiga jenis tipe penelitian studi kasus, yakni eksplorasi, eksplanatori dan deskriptif. Posisi studi kasus penelitian ini menggunakan tipe deskriptif, yang dijabarkan oleh Yin (2003) bahwa tipe deskriptif berusaha untuk menyajikan deskripsi lengkap tentang suatu fenomena dalam konteksnya, meneliti secara mendalam dan intensif untuk mendapatkan wawasan dan pemahaman tentang fenomena yang baru.

Untuk mengumpulkan data kualitatif dan mendapatkan gambaran secara utuh yang melibatkan suasana emosional dan atmosfer peristiwa yang alami, peneliti melakukan observasi terhadap subyek penelitian dengan mengikuti dalam kehidupan sehari-hari. Peran serta (participant observation) juga dilakukan peneliti. Cara ini membuat peneliti menjadi bagian atau terasosiasikan dengan subyek penelitian.

Untuk memperkaya dan memperdalam analisis, wawancara mendalam kepada informan warga masyarakat Suku Banjar dan suku lain, tokoh masyarakat, budayawan, dan kajian pustaka (literatur), sehingga bisa didapatkan persepektif yang lebih luas. Data dianalisis dengan teori Apropriasi Budaya.

\section{Hasil Penelitian dan Pembahasan}

\section{Identitas Kultural Dan Politik}

Sejak terpilih sebagai kepala daerah dalam pemilihan Gubernur Kalimantan Selatan tahun 2015 lalu, Sahbrin Noor yang sejak awal menyebut dirinya sebagai Paman Birin membawa warna yang berbeda dalam kepemimpinannya. Identitas kultural inilah yang dibangun Sahbirin Noor selama masa kepemimpinannya sebagai Gubernur Kalimantan Selatan. Dijelaskan informan bahwa:

"Meski menjabat sebagai kepala daerah dan pimpinan tertinggi dalam pucuk birokrasi pemerintahan daerah, ia ingin tetap dipandang sebagai sosok yang setara dan sederajat dengan siapapun. Menjadi Paman Birin baginya terasa lebih familiar dan santai, ketimbang menjadi sosok seorang gubernur yang memberinya batasan protokoler. Hadir sebagai Paman Birin di tengah masyarakat membuat Sahbirin Noor tak merasa canggung. Ia merasa tak harus menjaga pembawaannya sebagai gubernur dengan menjadi sosok yang berwibawa." 
Selanjutnya dikatakan informan budayawan:

"Masih banyak sebenarnya nilai budaya Banjar yang menjadi filosofi hidup masyarakat Banjar sejak dulu dan masih dipegang hingga saat ini. Nilai budaya Banjar itu juga yang menjadi prinsip hidup Sahbirin Noor jauh sebelum dirinya menjadi gubernur terpilih pertama kalinya pada tahun 2015. Nilai-nilai itu diakuinya diwarisi berkat didikan orang tua dan kehidupan yang dijalaninya di pinggiran sungai. Nilai kearifan masyarakat pesisir sungai membentuk mental dan karakater yang membuatnya meyakini bahwa dirinya adalah anak Sungai Martapura.”

Mengenakan sarung yang melingkar di leher atau dililitkan di pinggang, peci atau kopiah hitam bertengger di kepala, adalah ciri dan tampilan yang sering terlihat pada Sahbirin Noor. Adaptasi dan penggunaan identitas budaya Banjar dalam simbol-simbol etnik selama menjadi gubernur, menjadikan Sahbirin Noor tampil sebagai sosok pemimpin yang merepresentasikan urang Banjar.

Terkadang ia terlihat duduk bersama warga di warung-warung. Tak jarang ia juga ikut berbaur dalam acara kondangan perkawinan, gotong royong membantu hajatan warga, ikut tadurusan/mengaji di musala, sampai tidur bersama di rumah warga, adalah salah satu aktivitasnya saat berada di tengah masyarakat. Semua yang dilakukannya adalah ciri kekerabatan masyarakat Banjar yang kental dengan semangat gawi sabumi (gotong royong).

Istiqomah dan Setyobudihono (2014), mengungkapkan bahwa dalam "Nilai Budaya Masyarakat Banjar", terdapat empat nilai budaya Banjar, yaitu nilai budaya Banjar dalam hubungan manusia dengan Tuhan, hubungan manusia dengan manusia, hubungan manusia dengan diri sendiri atau berkaitan dengan kegiatan manusia sebagai bentuk pengembangan diri, hubungan manusia dengan alam atau lingkungan. Wujud nilai budaya Banjar dalam hubungan manusia dengan Tuhan, yaitu konsep berelaan yang merupakan penyerahan diri dengan rasa ikhlas dan pasrah sebagai wujud syukur atas semua kehidupan yang dijalani. Konsep berelaan ini merupakan refleksi keimanan seseorang dalam beribadah untuk mendapat keridhoaan Allah SWT. Dengan kata lain, konsep berelaan adalah nilai religius yang sangat erat dengan watak dan karakter masyarakat Banjar yang kental dengan nilai-nilai agama. Kemudian nilai budaya dalam konteks hubungan manusia dengan masyarakat tergambarkan dalam sistem kekerabatan, baik karena keturunan maupun karena status sosial. Konsep kekerabatan dikenal dengan prinsip bubuhan, yaitu mencakup nilai badingsanakan (persaudaraan), batulungan (saling menolong dan membantu), mau haja bakalah bamanang (mau saja kalah menang), maksudnya mau memberi dan menerima. Nilai-nilai budaya ini sering termanifestasi dalam kehidupan masyarakat Banjar dengan lebih mengedepankan sikap tenggang rasa, berbagi, empati, saling membantu, bergotong royong, dan tak mau memaksakan kehendak, karena mereka merasa adanya kesamaan hubungan personal dan emosional yang diikat secara budaya dan kesukuan. Istilah bubuhan atau papadaan sering menjadi ungkapan untuk menunjukkan adanya ikatan kekerabatan meski tak memiliki hubungan darah atau hubungan persaudaraan langsung. Dengan kata lain, dengan prinsip bubuhan atau papadaan, semua orang Banjar adalah saudara.

Selanjutnya nilai budaya dalam relasi manusia dengan dirinya sendiri tergambarkan dalam pengembangan diri dengan konsep gawi manuntung dan dalas balangsar dada. Nilai budaya ini mengandung prinsip bahwa sifat urang Banjar (orang Banjar) adalah pribadi yang ulet, tekun, tangguh, dan pekerja keras, dan mau berjuang dengan kesungguhan hati. Urang Banjar dinilai memiliki karakter dan sifat cangkal begawi, yaitu sifat tak mudah menyerah dengan kegagalan dan memiliki prinsip bekerja dengan sungguh-sungguh. Nilai budaya lain adalah 
dalam konteks manusia dengan alam yang tergambarkan dalam konsep bisa-bisa meandak awak, yaitu kemampuan untuk menyesuaikan dan menyelaraskan diri dengan alam dan lingkungan. Prinsip bisa-bisa meandak awak adalah konsep kemampuan menyesuaikan diri dengan situasi dan kondisi lingkungan di manapun berada. Dengan memegang teguh nilai budaya bisa-bisa meandak awak, membuat urang Banjar bisa mudah diterima dan bergaul dengan siapa saja secara kekeluargaan. Dengan kata lain, kemampuan adaptasi dengan menyesuaikan diri dengan lingkungan membuat urang Banjar lebih suka berteman dan tak ingin mencari musuh.

Dalam pengertian umum kebudayaan mencakup cara berpikir dan tingkah laku yang menjadi ciri khas suatu bangsa atau masyarakat tertentu. Unsur-kebudayaan meliputi bahasa, ilmu pengetahuan, hukum, agama, makanan, kesukaan, musik, kebiasaan, pekerjaan, kemasyarakatan, teknologi, dan sebagainya (Ihromi 2006: 7). Koentjaraningrat (2005: 3) menjelaskan bahwa kebudayaan yang dimiliki masyarakat mengandung sistem nilai-nilai budaya. Sistem nilai-nilai budaya terdiri atas konsepsi yang hidup dalam alam pikiran sebagian besar warga masyarakat mengenai hal-hal yang harus mereka anggap bernilai dalam hidup. Kerena itu, nilai budaya berfungsi sebagai pedoman tertinggi bagi kelakuan manusia. Djamaris (2002: 3) membagi nilai-nilai budaya dalam lima hubungan kelompok, yaitu 1) nilai budaya dalam hubungan manusia dengan Tuhan; 2) nilai budaya dalam hubungan dengan manusia dengan alam; 3) nilai hubungan dalam hubungan manusia dengan masyarakat; 4) nilai hubungan manusia dengan sesama manusia; 5) nilai hubungan manusia dengan dirinya sendiri.

Apa yang dilakukan Sahbrin Noor dalam pandangan teoritisi cultural studies menyatakan bahwa identitas dan subyek (diri) sangat terkait dan tidak dapat dipisahkan begitu saja. Subyektifitas adalah menyangkut diri (identitas pribadi) seseorang, di dalamnya tercakup perasaan, emosi, hasrat dan kemauan seseorang. Subyektifitas juga berkaitan dengan kesadaran (concious) dan ketidaksadaran (unconscious) seseorang. Identitas inilah kemudian menjadi rentan terhadap setiap perubahan yang terjadi disekitarnya. Sementara mengeksplorasi tentang identitas adalah menanyakan: bagaimana kita melihat diri kita sendiri dan bagaimana orang lain melihat kita? (Barker 2004: 173). Pertanyaan tersebut secara umum membagi identitas menjadi dua kategori utama, yakni pertama: identitas kultural dan identitas politik. Identitas kultural menentukan posisi subjek di dalam relasi atau interaksi sosialnya, sedangkan identitas politik menentukan posisi subjek di dalam suatu komunitas melalui suatu rasa kepemilikan (sense of belonging) dan sekaligus menandai posisi subjek yang lain di dalam suatu pembedaan (sense of otherness) (Barker 2018: 175-188).

\section{Identitas Sosial dan Personal Paman Birin}

Dalam kapastitas jabatannya sebagai Gubernur Kalimantan Selatan, Sahbirin Noor menjadi identitas sosial, karena hadirnya ia di tengah masyarakat dimaknai sebagai kepala daerah. Jabatan sebagai gubernur yang prestisius dan elitis menjadi simbol sosial yang membuatnya dihormati dan disegani. Sebagai gubernur saat menjalankan agenda kedinasan, Sahbirin Noor tampil dengan aturan protokoler. Identitas sosial sebagai gubernur yang melekat melalui simbol pakaian dinas, emblem, dan lambang jabatan, menandakan bahwa ia adalah pemimpin tertinggi pemerintahan daerah di Kalimantan Selatan.

Namun, ketika hadir di tengah masyarakat dengan menjadi Paman Birin, maka karakter yang muncul dan terlihat adalah identitas personal yang menampilkan sosok apa adanya. Tampil dengan simbol etnik seperti seperti sarung, peci, dan baju kaos, ia lebih mudah dan cepat diterima sebagia bagian dari kerabat dalam identitas sesama urang Banjar. Meski sebagai 
gubernur memiliki pengaruh dan kewenangan yang besar, namun keseharian Gubernur Sahbirin Noor lebih dikenal dan populer sebagai Paman Birin. Panggilan dan identitas personal Paman Birin lebih melekat pada sosoknya secara pribadi ketimbang dalam jabatannya sebagai Gubernur Kalimantan Selatan.

Popularitas dan sosoknya lebih dikenal sebagai Paman Birin, karena dalam interaksi dan komunikasinya lebih menggunakan pendekatan budaya ketimbang birokrasi yang ribet/merepotkan dan protokoler. Adaptasi yang dilakukan Sahbirin Noor dengan lebih menonjolkan sosok Paman Birin telah menyerap unsur dan nilai budaya Banjar dalam praktik birokrasi pemerintahan. Aturan protokoler dan birokrasi dalam bertatap muka dengan gubernur, jarak sosial antara pejabat dan rakyat, dan suasana psikologis yang membatasi relasi gubernur dan rakyat, semuanya mencair saat sosok dan identitas Paman Birin hadir di tengah masyarakat. Menurut informan:

"Warga telah terbiasa bertemu, berbincang dan bersenda gurau dengan Paman Birin di pasar, di warung atau bahkan di poskamling. Tak jarang tiba-tiba Paman Birin hadir di tengah acara perkawinan warga. Menjadi imam saat salat di musala, ikut membantu membersihkan sungai dan jalan, menanam padi, bercebur dan mandi di sungai, dan tidur di teras rumah warga. Kebiasaannya itu membuat citra dirinya sebagai Gubernur Kalimantan Selatan menjadi tak tampak, dan lebih dikenal sebagai Paman Birin, yang dianggap sebagai pemimpin sekaligus kawan.”

Sekat yang tipis antara Gubernur Kalimantan Selatan Sahbirin Noor dan Paman Birin sebagai Gubernur Kalimantan Selatan, membuat masyarakat seperti memiliki pemimpin dari kerabat sendiri. Ia lebih dikenal sebagai Paman Birin, dalam hal apapun, ketimbang dikenal sebagai Gubernur Kalimantan Selatan. Identitas adalah suatu esensi yang dapat dimaknai melalui tanda-tanda selera, kepercayaan, sikap, dan gaya hidup. Identitas dianggap personal sekaligus sosial dan menandai bahwa kita sama atau berbeda dengan orang lain (Barker 2018:174). Barker menyebut bahwa identitas sepenuhnya bersifat sosial dan kultural, karena alasan-alasan berikut: Pertama, pandangan tentang bagaimana seharusnya menjadi seseorang adalah pertanyaan kultural. Kedua, sumber daya yang membentuk materi bagi identitas, yaitu bahwa praktik kultural berkarakter sosial. Bila dilihat individu sebagai satu kesatuan yang utuh, sebenarnya konsep diri tidak hanya dibentuk oleh identitas personal, tetapi juga oleh identitas sosialnya. Karena apa yang disebut sebagai hubungan-hubungan sosial pada dasarnya merupakan sebuah kontinum, merentang dari hubungan yang berciri personal hingga yang berciri sosial (Afif 2015: 13).

\section{Apropriasi Budaya dalam Komunikasi Politik}

Salah satu pendekatan komunikasi yang dilakukan Gubernur Kalsel Sahbirin Noor adalah menciptakan slogan "Bergerak" yang artinya Berjuang Gelorakan Rakyat. Melalui semboyan ini, Sahbirin Noor alias Paman Birin, ingin mengadopsi nilai budaya Banjar cangkal bagawi (rajin bekerja) untuk menangkal kemalasan yang menjadi wabah dunia modern yang lebih berorientasi hasil daripada nilai. Bagi Paman Birin, masyarakat Banjar harus dibangunkan dan dimotivasi untuk bekerja lebih keras mengejar ketertinggalan dengan dunia luar.

Sahbirin Noor berkeyakinan bahwa masyarakat Banjar memiliki bekal nilai-nilai budaya dan tradisi yang cukup untuk hidup dan bersaing di segala zaman. Menurutnya, yang diperlukan hanyalah mengubah mental yang telah teracuni oleh virus-virus dunia modern dan memperkenalkan kembali ruh dan semangat orang-orang Banjar tempo dulu yang suka bekerja, 
berkomitmen, amanah dan pantang menyerah. Membangun Kalimantan Selatan melalui kebudayaan inilah yang ditempuh Gubernur Kalsel Sahbirin Noor dalam lima tahun kepemimpinanya.

Slogan ini menjadi simbol dan identitas personal yang melekat pada dirinya, dan sering menjadi yel-yel untuk memberi semangat. Kata bergerak selalu menjadi yel-yel dalam kegiatan atau acara formal kedinasan maupun saat berinteraksi langsung dengan warga. Bergerak kemudian menjadi slogan komunikasi politiknya yang sering terdengar dan diucapkan di manapun Paman Birin berada.

Secara sederhana komunikasi politik didefinisikan sebagai hasil yang bersifat politik apabila mereka menekankan pada hasil. Di sisi lain bagi mereka yang lebih menekankan fungsi komunikasi politik dalam sistem politik, maka komunikasi politik dapat didefinisikan sebagai komunikasi yang terjadi dalam suatu sistem politik dan diantara sistem tersebut dengan lingkungannya. Komunikasi politik dapat dilihat dalam arti sempit maupun dalam arti luas. Dalam arti sempit komunikasi politik adalah setiap bentuk penyampaian pesan, baik dalam bentuk lambang-lambang maupun dalam bentuk kata-kata tertulis atau terucapkan, ataupun dalam bentuk isyarat yang memengaruhi kedudukan seseorang yang ada dalam struktur kekuasaan tertentu. Dalam arti luas, komunikasi politik adalah setiap jenis penyampaian pesan, khususnya yang bermuatan info politik dari suatu sumber kepada sejumlah penerima pesan. Komunikasi politik berkaitan dengan masalah manusia dan hubungan sosial mengingat komunikasi adalah kajian tentang komunikasi manusia (human communications). Politik adalah kajian tentang gejala kekuasaan antara sesama manusia beserta relasi yang dibangun dalam lembaga-lembaga yang memiliki dimensi kekuasaan. Kedekatan antara komunikasi dan politik jelas merupakan suatu hal yang selalu terjadi dalam kehidupan sehari-hari. Jika politik merupakan kebijakan tentang pembagian nilai-nilai oleh pihak yang berwenang, maka kebijakan dibuat berdasarkan pesan-pesan yang disalurkan antara satu orang dengan orang lainnya agar kebijakan yang dibuat tidak sepihak dan menimbulkan konflik diantara kepentingan yang berbeda. Secara umum setiap inidvidu atau kelompok politik akan memilih media komunikasi yang efektif untuk meraih tujuan.

Apropriasi budaya Banjar berupa papadaan dan bubuhan dalam hubungan komunikasi dan interaksi langsung menjadi ciri yang melekat pada diri Sahbirin Noor. Gaya bicaranya yang lepas, seakan tak sadar bahwa dirinya adalah seorang gubernur, menjadi kebiasaannya yang sudah dipahami semua warga yang berinteraksi dengannya. Dengan menjadi Paman Birin, tak membatasi dirinya dalam bergaul, dengan siapa saja dari semua lapisan masyarakat bawah hingga para pejabatnya. Caranya bicaranya, dengan bahasa dan pilihan kata yang lebih mudah dipahami dalam bahasa Banjar, adalah bentuk komunikasi lintas generasi yang bisa diterima siapa saja, dari anak-anak hingga mahasiswa, dari pejabat hingga tukang becak.

Ciri lain yang menjadi identitas personalnya adalah kepiawaiannya berpidato dalam setiap acara. Lantang, penuh semangat, dan suara yang tegas penuh wibawa, ditambah mimik dan bahasa tubuh yang meyakinkan, membuatnya dikenal sebagai orator andal dalam setiap acara. Boleh dibilang dalam komunikasi politiknya, Paman Birin adalah sosok yang mampu menghipnotis bila dia berdiri di hadapan audiens secara langsung. Sebagai komunikator ia selalu menggunakan kata dan bahasa yang paling mudah dipahami oleh semua lawan bicaranya. Pesan yang disampaikan sangat kental dengan petuah bijak dan nilai-nilai budaya Banjar. Ia merasa bahwa sebagai anak sungai yang lahir dan besar di kota yang penuh dengan nilai dan kearifan lokal budaya Banjar, maka berkomunikasi dengan bahasa dan simbol-simbol budaya Banjar lebih mudah diterima. 
Slogan Bergerak menjadi ciri dan identitas personal Paman Birin yang menggambarkan dirinya sebagai sosok Urang Banjar. Dengan mengucap kata Bergerak, Paman Birin ingin menunjukkan bahwa ia selalu menggunakan pendekatan budaya sebagai salah satu strategi komunikasinya dalam mendekatkan dan merekatkan secara emosional dengan semua orang yang berinteraksi dan berkomunikasi dengannya. Bergerak, yang artinya Berjuang Gelorakan Rakyat, kemudian menjadi slogan yang identik dengan identitas Urang Banjar, yaitu ajakan untuk bersama-sama mengalahkan segala bentuk kemalasan sebagai penyakit sosial masyarakat modern saat ini. Dengan slogan Bergerak, Paman Birin ingin mengembalikan semangat dan nilai-nilai budaya Banjar dalam kehidupan masyarakat Kalimantan Selatan. Bergerak tak lagi menjadi slogan semata, tapi sudah menjadi identitas personal Paman Birin yang populer dan menjadi ciri dirinya setiap berkomunikasi dan berinteraksi dengan siapapun.

Dalam interaksinya baik secara keseharian maupun dalam menjalankan tugas pokok dan fungsi sebagai gubernur, Sahbirin Noor mengadopsi nilai-nilai budaya Banjar dalam komunikasinya dengan warga dan lingkungan di manapun ia berada. Dengan prinsip kekerabatan bubuhan papadaan, Sahbirin Noor terlihat ingin ta'mpil apa adanya. Gaya bicaranya, pesan yang disampaikan, bahasa yang terucapkan, hingga saluran dan media komunikasi yang digunakan pun lebih banyak melalui interaksi secara langsung. Sahbirin Noor termasuk tipe urang Banjar yang merasa lebih bergairah bila berbicara dan berdiskusi melalui tatap muka secara langsung. Tempatnya pun bisa di mana saja, dalam kondisi apa saja, dan dengan siapa saja. Warung dan rumah warga adalah tempat yang sering menjadi lokasi perjumpaan dan komunikasi antara Sahbirin Noor dan warga. Kebiasaan masyarakat Banjar yang suka berkumpul dan berbincang dalam suasana santai dan penuh keakraban di warung menjadi tradisi yang lazim ditemukan, yaitu mewarung (berbincang dan berkumpul di warung).

\section{Apropriasi Kayuh Baimbai dalam Kerja Bersama}

Bakayuh Baimbai artinya adalah mengayuh bersama dalam sebuah perahu. Falsafah ini melambangkan sebuah pekerjaan yang sulit akan semakin mudah jika "dikayuh" atau dikerjakan bergotong royong bersama-sama. Sebuah perahu akan bergerak lambat jika hanya dikayuh oleh satu orang. Tetapi jika semua orang dalam perahu mengayuh, mengerjakan apa yang mereka mampu lakukan untuk tujuan yang sama, maka perahu akan melaju deras di atas sungai. Dalam khazanah kearifan lokal Banjar, Kayuh Baimbai adalah falsafah yang sangat penting. Sudah sangat lama, leluhur Urang Banjar mengingatkan perumpamaan ini sebagai nilai-nilai yang harus dipegang oleh sebuah pribadi dalam masyarakat. Tidak ada yang bisa dicapai jika tidak ada kesatuan niat, komitmen dan semangat. Seperti sebuah perahu, sebuah pekerjaan tidak akan berjalan jika tidak dikayuh bersama. Apalagi, jika orang-orang dalam perahu mengayuh ke arah yang berbeda. Niscaya perahu tidak akan bergerak. Menurut informan budayawan:

"Spirit Kayuh Baimbai ini menjadi salah satu nilai-nilai budaya Banjar yang selalu disuarakan melalui slogan Bergerak. Dalam setiap pidatonya, Sahbirin Noor selalu mengingatkan agar setiap elemen dalam masyarakat harus bisa "bergerak" untuk membawa perahu kemajuan Kalsel bersama-sama. Tak sekadar bicara dan beretorika, sebagai pembuktian spirit Kayuh Baimbai, Sahbirin Noor selalu mencontohkan secara nyata dalam kepemimpinannya. Dia tidak segan-segan turun langsung ke lapangan untuk bekerja. Puncak pembuktian Sahbirin Noor dalam mengimplementasikan spirit Kayuh Baimbai adalah saat Kalimantan Selatan diberi kepercayaan pemerintah pusat untuk sebagai tempat penyelenggaraan Hari Pangan Sedunia (HPS) ke XXXVIII Tahun 
2018. Skala dari event yang besar ini membuat pekerjaannya bisa menjadi beban bagi provinsi yang menanggungnya."

Acara internasional dikerjakan oleh orang-orang lokal tentumenjadi kesulitan tersendiri. Bukan tidak mungkin, penyelenggaraan yang buruk akan menjadi aib bagi Kalsel dan pada masyarakat Banjar pada umumnya. Itu baru permasalahan pertama. Permasalahan kedua, lahan pertanian yang ditunjuk pusat berada di kawasan rawa. Banyak pihak menjadi sangsi dan pesimistis. Bertani di tanah rawa? Seperti menegakkan benang yang basah. Tingkat keasaman yang tinggi membuat hara-zat utama untuk pertumbuhan tanaman-menjadi sangat minim. Bahkan petani yang paling terampil dan berpengalaman pun akan gentar. Permasalahan ketiga, adalah luasan lahan yang akan dibangkitkan: 4.200 hektar! Dengan 97 hektar diantaranya harus sudah menjadi lahan yang ditanami padi sebagai syarat dari penyelenggaran Hari Pangan Sedunia. Menanam padi di lahan gambut yang penuh belukar saja sudah sulit, apalagi di lahan rawa yang sangat luas. Ini seperti pekerjaan yang mustahil. Menurut informan Paman Birin:

"Saya menerima tugas itu dengan penuh keyakinan. Saya mengenali setiap potensi dan percaya dengan spirit Kayuh Baimbai Urang Banjar. Dengan mengadopsi nilai dari spirit Kayuh Baimbai atau gotong royong yang telah lama menjadi tradisi budaya Banjar sejak dulu, maka saya yakin tidak ada beban yang terlalu berat untuk dipikul jika semua orang mencurahkan tenaga dan usahanya bersama-sama. Tradisi gotongroyong dalam urat nadi kebudayaan mereka. Yang diperlukan hanyalah motor penggerak untuk membuat mereka bersemengat untuk bergerak."

Sahbirin Noor pun sebagai seorang pemimpin mengambil posisi itu. Untuk menggelorakan semangat mereka, Sahbirin turun ke lahan berlumpur dengan luas ribuan hektare di Jejangkit Muara, Barito Kuala. Dia mengenakan pakaian bahuma (bertani) lengkap dengan pupur dingin (bedak basah) di wajahnya, tak ubahnya seperti para petani tradisional Banjar. Dia benar-benar berada di garis terdepan untuk membuka lahan dan bercocok tanam di tanah yang semula tidak produktif itu. Sahbirin Noor mengajak semua elemen di Kalimantan Selatan untuk mewujudkan mimpi besar ini. Warga Kalsel utamanya yang sekian puluh tahun lamanya berdiam di daerah itu pun terkesima. Mereka tak menyangka ada semangat dalam event besar itu. Sahbirin Noor mencurahkan perhatiannya setiap hari untuk proyek besar di Jejangkit Muara. Dia memantau setiap kemajuan dan memberi arahan setiap pekerjaan. "Dia sering menginap di pondokan areal sawah di sana. Pagi atau sore hari, Paman Birin ikut membuka lahan dan menanam benih padi," kata Zainal, seorang warga Jejangkit menuturkan.

Beragam kesaksian seperti ini membuat masyarakat setempat terbakar semangatnya. Semakin hari, semakin banyak orang yang bergabung dalam kerja membuka lahan ribuan hektare untuk menjadi persawahan sebagai persyaratan dari kehormatan menjadi tuan rumah Hari Pangan Sedunia. Semua elemen dari berbagai profesi lainnya ikut turun karena merasa terpanggil. Semua pejabat dan seluruh staf dinas dan badan lingkup Pemerintah Provinsi Kalimantan Selatan, tentara, mahasiswa, petani, wartawan, pelajar, hingga atlet pun ikut Kayuh Baimbai bergotong royong membantu terjun langsung menanam padi.

Mereka ingin menjadi "kayuh" dalam sebuah perahu yang sedang bergerak. Semakin banyak orang yang turun ke sawah membuat pekerjaan yang tadinya seperti tidak mungkin ini akhirnya menjadi sangat mudah. Kala waktu semakin dekat, semua orang justru menjadi semakin termotivasi. Ribuan orang berada di areal persawahan untuk membuka dan menanam benih padi. Para pakar dan akademisi serta ahli teknologi pertanian membuat terobosan dan menguji setiap prosedur dengan hati-hati. Lahan kering yang tak ramah tanaman ditaburi banyak pupuk 
sebagai pondasi tanam, sedangkan dalam lahan rawa, pemerintah membuat mekanisasi irigasi modern dan menebar pompa yang memungkinkan lahan yang penuh air bisa ditumbuhi tanaman padi.

Pemerintah Provinsi Kalsel juga bekerja keras membangun infrastruktur strategis. Memudahkan akses permanen, menambahkan lampu penerang jalan, membuat sarana penunjang agar setiap orang tak kesulitan untuk datang. Sebuah kawasan sepi di desa disulap dalam waktu "semalam" menjadi seperti kota kecil dengan gairah pembangunan yang berdenyut. Demikianlah, Hari Pangan Sedunia yang digelar pada 18 Oktober 2018 itu menjadi momen yang monumental. Ribuan tamu dari seluruh Indonesia dan mancanegara berdecak kagum. Menteri Pertanian kala itu, yang datang memandang hamparan padi di Jejangkit dengan raut wajah optimistis. Dia bukan saja memuji Kalimantan Selatan telah menciptakan sejarah dan mencatatkan diri sebagai daerah penyelenggara event besar itu, tetapi juga menahbiskan Kalimantan Selatan sebagai daerah penyangga pangan nasional. Sebuah status yang sebenarnya mustahil didapatkan mengingat kontur rawa di Kalimantan Selatan yang susah ditanami padi.

Itulah, pekerjaan besar Hari Pangan Sedunia melambangkan kekuatan dari falsafah Kayuh Baimbai. Gubernur Kalsel Sahbirin Noor tidak surut dengan tantangan karena percaya tradisi Kayuh Baimbai Urang Banjar bisa memberikan jawaban akan problem-problem besar. "Kita punya target yang sangat luar biasa, maka itu perlu bergotong-royong bersinergi. Jika kita semua bersinergi dan Bekayuh Baimbai, harapan target penanaman dapat kita capai," ucap Sahbirin Noor usai acara kala itu. Sahbirin Noor berhasil membawa spirit Kayuh Baimbai dalam kepemimpinannya dan membawanya dalam aksi-aksi nyata. Nilai-nilai dan spirit dalam budaya Banjar, salah satunya spirit Kayuh Baimbai atau gotong royong, diwujudkannya dalam aksi nyata menggerakkan semua komponen masyarakat dalam program pembukaan dan penanaman padi dalam peringatan Hari Pangan Sedunia.

\section{Apropriasi Tradisi Mewarung Menyerap Aspirasi}

Sejak menjabat sebagai Gubernur Kalimantan Selatan, Sahbirin Noor alias Paman Birin lebih suka berinteraksi dan berkomunikasi langsung dengan warga. Dengan mengendarai sepeda motor trail, ia bersama dengan jajarannya dan unsur Forum Komunikasi Pimpinan Daerah (Forkopimda), menjelajahi kawasan-kawasan terpencil di Kalimantan Selatan. Ada satu tradisi dan kebiasaan masyarakat Banjar yang suka berkumpul dan berbincang, dan kemudian diadopsi Paman Birin sebagai cara untuk berkomunikasi dan menyerap aspirasi secara langsung. Tradisi atau kebiasaan itu adalah mewarung atau berkumpul di warung sambil ngobrol, bercanda, atau berdiskusi. Kebiasaan atau kesukaan masyarakat berkumpul ini tak hanya di warung, tapi bisa juga dalan acara hajatan warga, atau sekedar berkumpul di rumah warga. Sahbirin sepertinya sangat memahami bahwa pola komunikasi dan interaksi langsung dalam suasana yang santai membuat penyampaian aspirasi dari bisa lebih terbuka. Dalam Musyawarah Perencanaan Pembangunan Daerah (Musrenbang) di awal kepemimpinannya, dia telah menggagas suatu bentuk konsep penjaringan aspirasi yang digabung dengan hobi motor trail.

Istilah Turdes (turun ke desa) dan semboyan Bergerak pun mulai populer sejak saat itu. Turdes adalah cara dan upaya yang dilakukannya untuk menguji aspirasi yang sampai ke pemerintah provinsi dengan mendengar langsung keluhan masyarakat di desa-desa. Caranya, dengan berkumpul bersama warga di warung, di rumah warga, atau ikut bersama dalam acara hajatan. Di awal Musrenbang 2016, tahun-tahun pertama kepemimpinannya, Paman Birin mengajak unsur Forkopimda dan sejumlah kepala Satuan Kerja Perangkat Daerah (SKPD) lingkup pemerintah provinsi Kalimantan Selatan turun ke desa selama 4 hari 4 malam. Rute bersepeda 
motor dimulai dari halaman kantor setdaprov menuju ke Serongga, Kabupaten Kotabaru. Di sini, Paman Birin menembus jalur-jalur "neraka" kubangan lumpur, jalanan rusak yang lama sudah tak tersentuh perbaikan serta tebing berbatu-batu yang membahayakan. Dari sini, Paman Birin kemudian segera merasakan bagaimana susahnya para penduduk di desa-desa membawa barang-barang dagangan mereka ke kota. Saat itu juga, Paman Birin memerintahkan jajaran Dinas Pekerjaan Umum untuk memprioritaskan pembangunan jalan di pelosok Kotabaru. Di Serongga, Paman Birin segera bermusyawarah dengan para penduduk di desa-desa untuk menyelesaikan permasalahan-permasalahan lingkungan dan sosial mereka. Dia juga membagibagikan banyak bantuan untuk pendidikan dan kesehatan sebagai "oleh-oleh" mereka. Semua warga mengelu-elukan Paman Birin.

Dari Kotabaru, Paman Birin dan rombongan menembus jalur-jalur berbahaya nan sepi menuju ke hulu sungai. Di sepanjang jalan dalam rute itu, Paman Birin menyapa penduduk sekadar menanyakan bagaimana kehidupan mereka. Dia bisa menilai kemajuan sebuah desa melalui cerita-cerita yang disampaikan oleh para penduduk di kawasan terpencil. Beberapa penduduk desa bahkan bercerita, di sana belum pernah melihat kendaraan bermotor selama bertahuntahun karena tidak ada akses jalan yang memadai menuju perkampungan mereka. Paman Birin memikirkan, andai saja, dia tidak mengendarai motor trail, dia tidak mengetahui bahwa ada permukiman terpencil di balik hutan dan rawa-rawa sungai. Dia bersyukur bisa bertatap muka langsung dengan rakyat yang dipimpinnya. Akhirnya, setelah berhari-hari, turdes pun berakhir di Loksado, Kabupaten Hulu Sungai Selatan. Di sana, Paman Birin menggemakan pariwisata Kalimantan Selatan dengan Festival Bamboo Rafting. Apa yang dicapai dengan semua lelah ini? "Dengan turdes ini," jawab Paman Birin, "kita bisa membuktikan bahwa pemerintah ada untuk rakyat. Bahkan bagi rakyat yang ada di ujung di mana burung berbunyi." Bagi Paman Birin, desa adalah tempat pelestarian nilai-nilai tradisional. Di sanalah disemai nilai-nilai budaya lama yang adiluhung. Karena itu, Paman Birin memiliki keberpihakan yang jelas secara personal ke desa. Dia memiliki kebiasaan bermusyawarah di desa untuk merasakan antusias masyarakatnya dan sambutan mereka yang hangat. Kepada mereka, Paman Birin mengatakan warga desa berhak untuk mendapatkan semua fasilitas dan pelayanan sebagaimana masyarakat perkotaan. Setahap demi setahap dia mewujudkan kemajuan bagi desa dan berusaha untuk hadir menjawab semua aspirasi dan keluhan-keluhan mereka. "Saya ingin mendengar langsung aspirasi masyarakat dan menyaksikan kondisi ekonomi dan pembangunan desa," ucapnya saat itu. Ada 2000 lebih desa di Kalsel dan Paman Birin mengupayakan untuk mendengar keinginan mereka secara langsung.

\section{Simpulan}

Apropriasi budaya Suku Banjar dilakukan Paman Birin dalam proses pemilihan kepala daerah/gubernur dan ketika terpilih dan memimpin Propinsi Kalimantan Selatan. Gaya kepemimpinan gubernur Paman Birin, ditunjukkan dengan identitas kultural, sosial, politik dan personal melaui apropriasi kayuh baimbai/gotong royong dalam kerja bersama, apropriasi tradisi mewarung untuk menyerap aspirasi masyarakat, apropriasi budaya dalam komunikasi politik.

Paman Birin sangat memahami dan menyadari bahwa pendekatan budaya dengan menjadi bagian kekerabatan sebagai sesama Urang Banjar membuatnya lebih mudah diterima tanpa rasa canggung. Itulah mengapa ia lebih suka menonjolkan identitas pribadinya sebagai Urang Banjar dalam menjalankan tugas dan aktivitasnya. Baik saat melaksanakan tugas formal pemerintahan maupun dalan aktivitas kehidupan sehari-hari. 
Mengadopsi pendekatan budaya ternyata lebih efektif bagi Paman Birin saat menjalankan tugas pemerintahan maupun saat beraktivitas sehari-hari. Model kepemimpinan Gubernur Kalimantan Selatan Sahbirin Noor dengan menonjolkan identitas personal sebagai Paman Birin adalah bentuk adaptasi dan apropriasi budaya dengan memasukkan semua nilai dan tradisi budaya Banjar dalam kepemimpinannya. Adaptasi nilai budaya dalam aktivitasnya sebagai kepala daerah membuat dirinya lebih mudah berkomunikasi dan berinterakasi tanpa dibatasi oleh aturan protokoler.

Hal yang sama juga dirasakan oleh masyarakat Kalimantan Selatan, yang merasa lebih leluasa dan tak merasa canggung bila berkomunikasi dan berinteraksi secara langsung. Tak ada aturan protokoler dan simbol identitas sosial sebagai gubernur, malah sebaliknya yang terlihat adalah identitas etnik seperti sarungan, peci, dan bahasa Banjar yang menjadi pengantar komunikasi sehari-hari Paman Birin.

Meski menjabat sebagai gubernur dan kepala daerah, namun simbol etnik sebagai politik identitas gubernur Kalsel, membuat Paman Birin lebih popuper dan dikenal sebagai Papadan Urang Banjar (sesama orang Banjar). Sahbirin Noor lebih dikenal sebagai simbol etnik Paman Birin, dibanding Gubernur Kalimantan Selatan Sahbirin Noor. Dengan kata lain, Paman Birin adalah Gubernur Kalsel, dan Gubernur Kalsel adalah Paman Birin.

\section{Daftar Pustaka}

Afif, A. (2015). Teori Identitas Sosial.Yogyakarta: UII Press.

Barker, C. (2018). Cultural Studies. Yogyakarta: Kreasi Wacana Offset.

Barendregt, B. dan Bogaerts, E. (2016) Merenungkan Gema Perjumpaan Musikal IndonesiaBelanda, Jakarta: Yayasan Obor Indonesia.

Djamaris, E. (2002) Pengantar Sastra Rakyat Minangkau. Jakarta: Yayasan Obor Indonesia.

Hancock, D. R dan Algozzine, B. (2006) Doing Case Study Research: A Practical Guide for Beginning Researchers. Columbia University, Teachers College.

Ihromi, T.O. [Ed.] (2006) Pokok-Pokok Antropologi Budaya. Banjarsari: Yayasan Obor Indonesia.

Istiqomah, E. dan Setyobudihono, S. (2014) Nilai Budaya Masyarakat Banjar Kalimantan Selatan: Studi Indigenous. Jurnal Psikologi dan Teori Terapan, 5 (1): 1-6. https://doi.org/10.26740/jptt.v5n1.p1-6.

Koentjaraningrat (2005) Pengantar Antropologi I. Jakarta: Rineka Cipta.

Rogers, R. A. (2006) From Cultural Exchange to Transculturation: A Review and

Reconceptualization of Cultural Appropriation. Communication Theory, 16 (4): 474503. https://doi.org/10.1111/j.1468-2885.2006.00277.x.

Sanders, J. (2006) Adaptation and Appropriation New Critical Idiom. USA \& Canada: Routledge.

Yin, R. K. (2003) Case Study Research (Design and Methods) Third Edition. California : Sage 
Biokultur, Volume 10, Number 2, 2021, Page 120-134

Publication Inc.

Young, J. O. (2008). Cultural Appropriation and the Arts. Malden, Oxford, Carlton: Blackwell Publishing.

Zuhro, R. S. (2009) Peran Aktor Dalam Demokratisasi. Yogyakarta: Ombak. 